
Dragoș POPESCU

De la parc totalitar la piață democratică. Reorganizarea și amenajarea spațiului public central din municipiul Râmnicu Vâlcea From totalitarian park to democratic plaza. Reformation and design of central public space from Râmnicu Vâlcea municipality
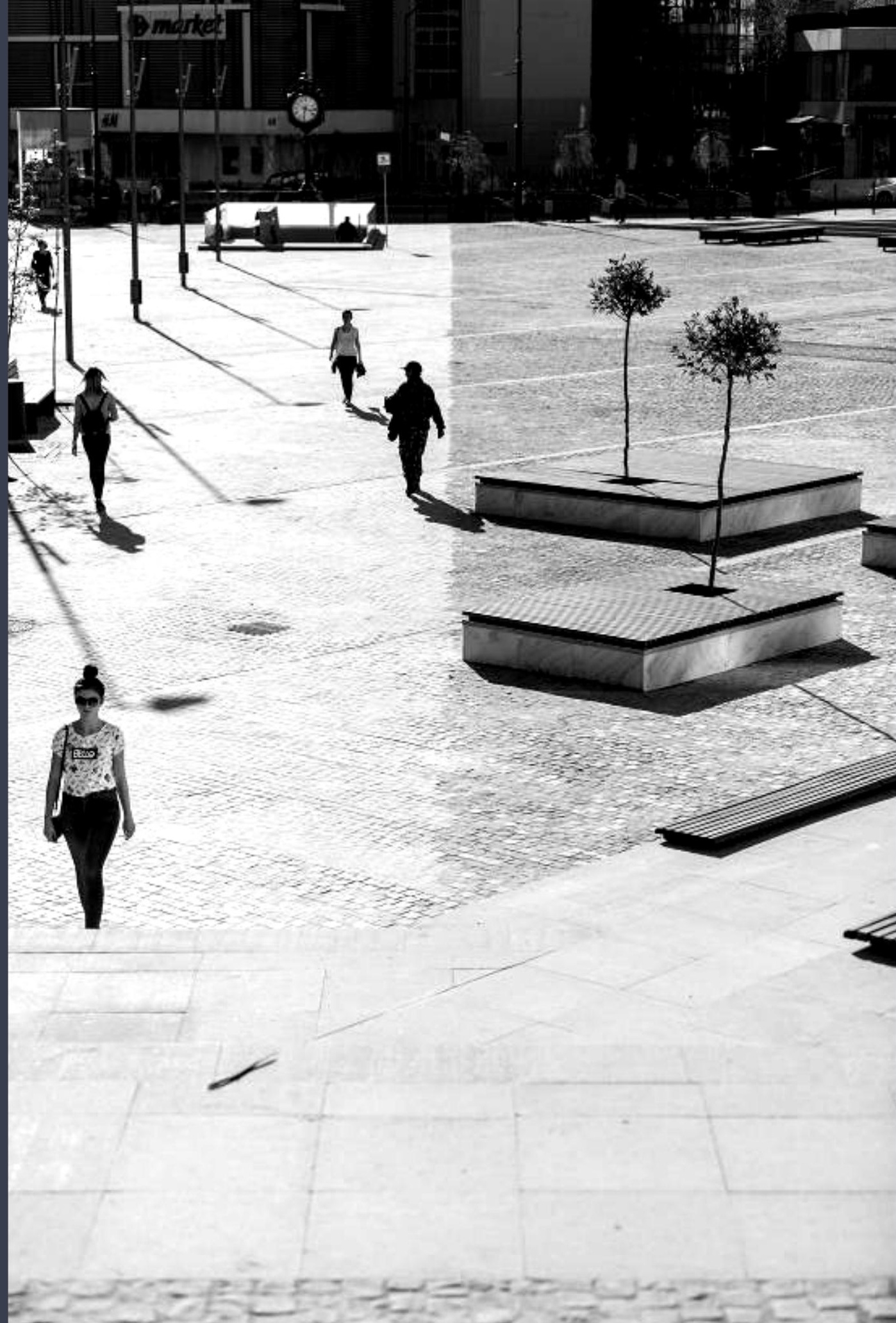
De la parc totalitar la piață democratică. Reorganizarea și amenajarea spațiului public central din municipiul Râmnicu Vâlcea

From totalitarian park to democratic plaza. Reformation and design of central public space from Râmnicu Vâlcea municipality

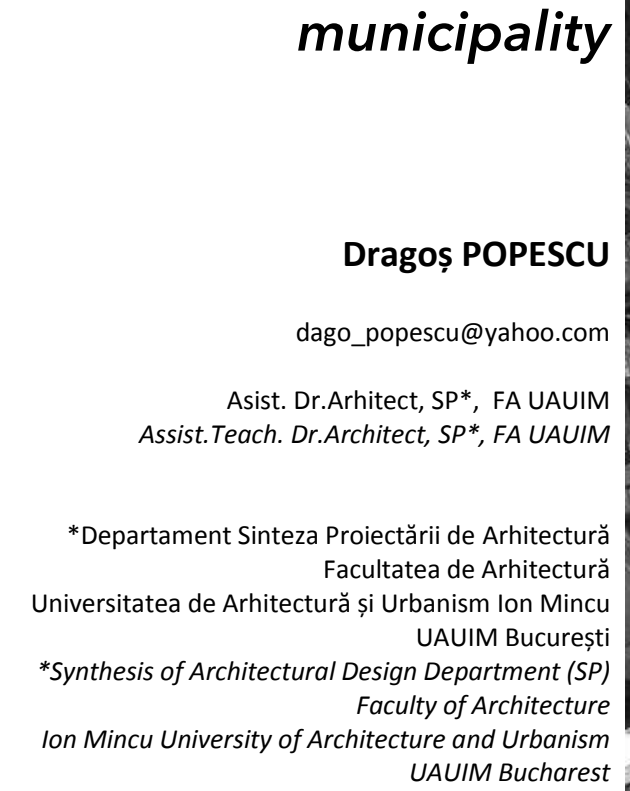

rezumat

Zona centrală din Râmnicu-Vâlcea a fost, in 2012, subiectul unui concurs național de soluții de arhitectură, organizat de OAR. Se dorea intervenția pe două paliere, mai întâi conturarea unei strategii asupra unei zone mai extinse, propunerea unor trasee pietonale fluente, reconsiderarea funcțiunilor spațiului public și conexiunile cu restul zonei centrale. A doua intervenție propusă era asupra unui scuar central (Mircea cel Bătrân), pentru crearea unui spațiu public de maxim interes pentru pietoni, o legătură cât mai bună cu zonele comerciale de la sud și rezolvarea traficului auto și pietonal în zonă.

cuvinte cheie

arhitectură, concurs, spațiu public abstract

Râmnicu Vâlcea is a small-to-medium size city, the head of one of Romania's 42 counties. It's located in the centre of the country, at the foothills of the Carpathian Mountains. The central area of the town was the subject of a national architectural competition in 2012. There were two areas to intervene upon: a larger one, aiming at the creation of pedestrian zones, new public spaces and their connections with the rest of the central area. A second focus was on a very central space, having a park-like organization at the time, which was to be converted into a major public space. keywords

architecture, competition, public space

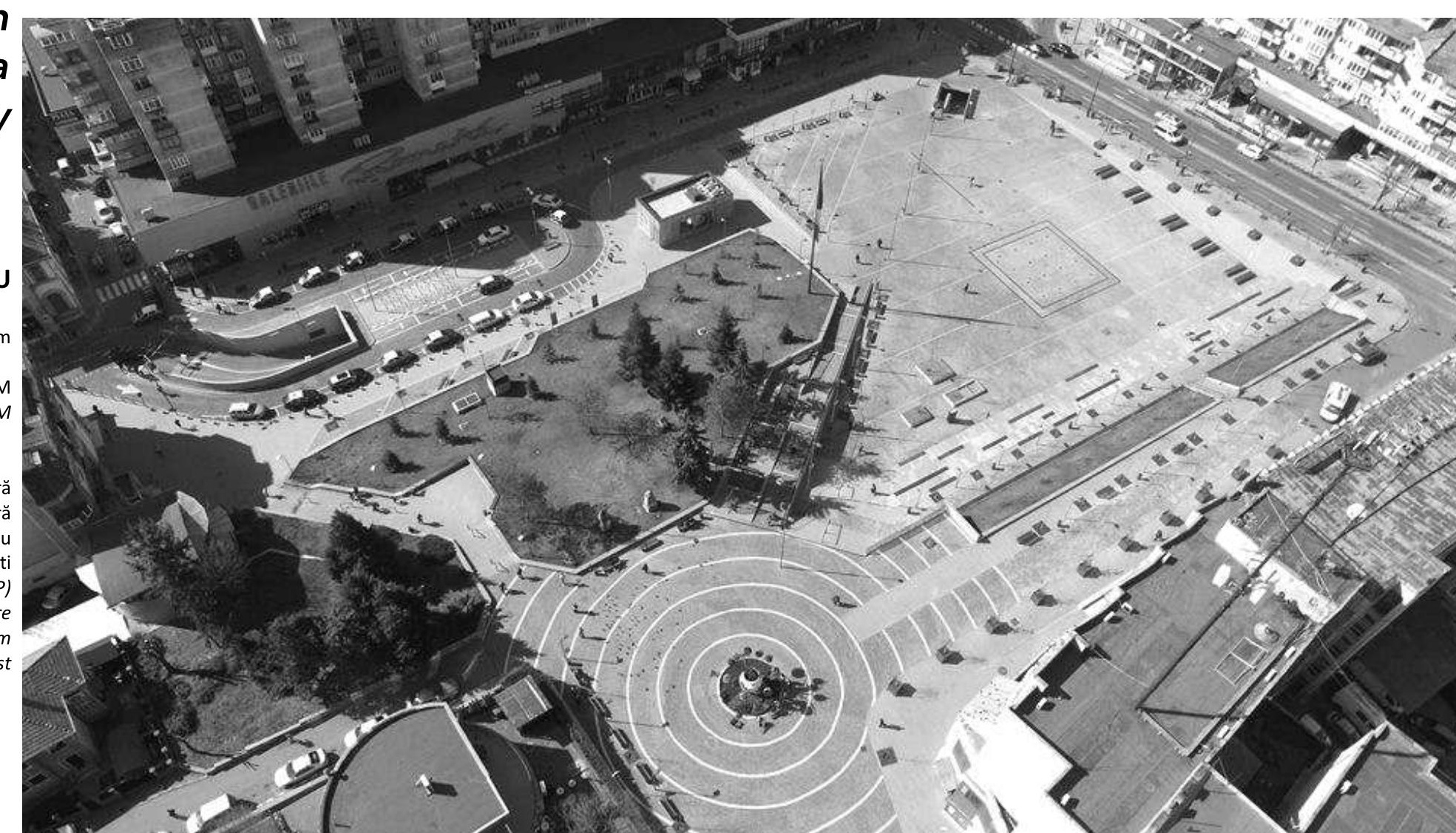




\section{STADIUL INITIAL}

Zona centrală din Râmnicu-Vâlcea a fost, in 2012, subiectul unui concurs național de soluții de arhitectură, organizat de OAR. Se dorea intervenția pe două paliere, mai întâi conturarea unei strategii asupra unei zone mai extinse, propunerea unor trasee pietonale fluente, reconsiderarea funcțiunilor spațiului public și conexiunile cu restul zonei centrale. A doua intervenție propusă era asupra unui scuar central (Mircea cel Bătrân), pentru crearea unui spațiu public de maxim interes pentru pietoni, o legătură cât mai bună cu zonele comerciale de la sud și rezolvarea traficului auto și pietonal în zonă.

În urma analizei pe care echipa noastră câștigătoare a făcut-o, impresia noastră a fost că orașul nu suferea de disfuncționalități majore, ci doar de o viziune învechită despre spațiul public, trafic și în general confort urban.

Centrul Municipiului Râmnicu-Vâlcea a trecut, începând cu anii '50 dar în special în anii ' 80 , printrun proces de restructurare specific acelei perioade. Zona centrală a suferit un proces de reconstrucție de tip tabula rasa, în care singurele elemente menținute au fost câteva construcții, actualmente cu statut de monument. Deși traseele străzilor au fost păstrate, prospectele s-au mărit, iar casele au fost dărâmate și înlocuite cu blocuri noi.

\section{SCOPUL INTERVENTIIEI}

Scuarul subiect al concursului de amenajare se afla pe amplasamentul unei astfel de insule urbane, străbătute de o stradă diagonală. Ea a fost transformată într-o amenajare de tip parc cu alei și garduri vii, specifică regimurilor totalitare, în care oamenii erau descurajați să se reunească în spații publice, în logica lui Circulați, vă rog!, conform căreia orice spațiu public este de fapt un traseu de deplasare iar staționarea este interzisă.

Ca reacție la acest tip de intervenție, ne-am propus să încercăm să găsim soluția optimă pentru crearea unui spațiu public central atât de necesar, un spațiu al democrației, care să contribuie la redescoperirea de sine a comunității locale, a spiritului civic. Am vrut să facem asta fără o intervenție în forță care să șteargă tot ce exista înainte pe acest loc, așa cum se întâmplase în trecut.

\section{DESCRIEREA INTERVENTIEI}

În primul rând, am identificat zonele cu calități pozitive, ce puteau fi păstrate. Astfel, zona verde de la sud-estul ansamblului avea calități spațiale deosebite, preluând fericit panta naturală a terenului, păstra o direcție de parcurgere utilă prin scara Boromir, constituind în același timp o rezervă esențială de spațiu verde.

Datorită unei diferențe de nivel de peste trei metri pe direcția nord-sud (și o alta mai mică pe direcția est-vest), amenajarea de tip scuar existentă consta în platforme la cote diferite, cu zone verzi intercalate. De aceea, din punct de vedere al utilității sale, scuarul Mircea Cel Bătrân era o rezervă imensă de spațiu nefolosit din cauza amenajării sale ca parc cu alei și nu ca spațiu public. Ce trebuia făcut era să deschidem întregul spațiu. Am făcut-o creând un unic spațiu amplu, rectangular, Piața Mare. larba a fost în bună măsură înlocuită cu pavaje, iar pomii au fost distribuiți pe aliniamente perimetrale, pentru a nu obtura vederea în cazul evenimentelor de amploare.

În același timp, un alt factor determinant propunerii noastre a fost considerentul că spațiile publice trebuie să fie plate pentru a permite
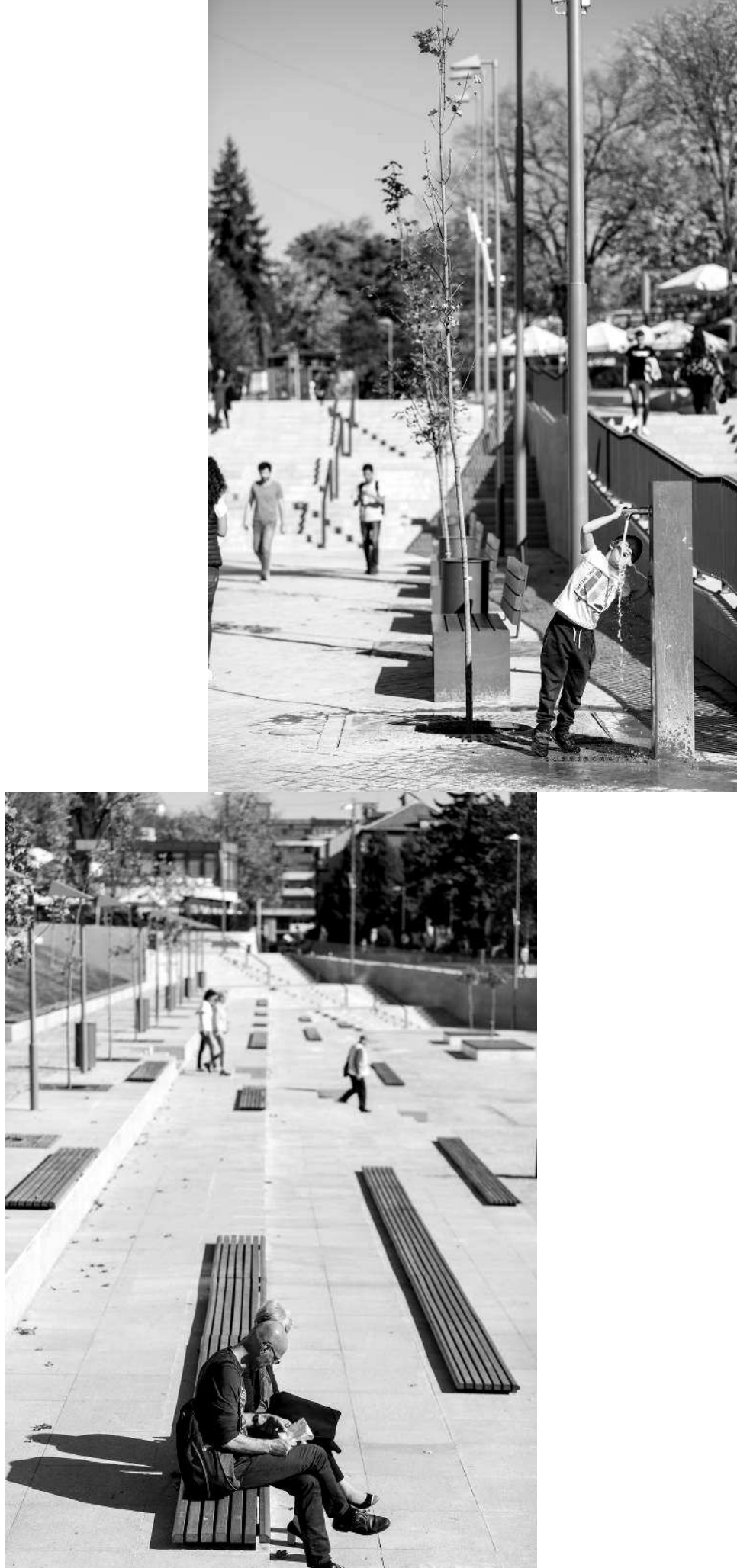

originale din proiectul de la concurs. Deasupra parcării, în jurul rampei de acces, s-a reamenajat o stație de taxiuri și o parcare de biciclete. Accesul pietonal în parcare este o cutie de sticlă cu fețe clare alternând cu panouri translucide ce îmbracă o carcasă din beton aparent. S-a dorit diminuarea prezenței acesteia în spațiul public, prinderile punctuale din inox și soclul retras contribuind la senzația de dematerializare.

Tronsonul străzii Regina Maria de la sudul amenajării, ce beneficiază de o sumedenie de spații comerciale, a fost pietonalizat, odată cu aducerea zonei ocazional carosabile la nivelul trotuarului. Accesele carosabile spre zona centrală au fost restricționate prin bolarzi de piatră și electrici.

\section{EVALUAREA INTERVENTIE}

De la inaugurarea publică a amenajării (octombrie 2017), deja noul spațiu public a găzduit numeroase evenimente, mari și mici. Ne-am bucurat să vedem că versatilitatea maximă a unui spațiu plat și rectangular, înconjurat de scări și gradene, a fost speculată în diverse manifestări culturale: piese de teatru, concerte, evenimente s-au adaptat la noua topografie, beneficiind de vizibilitatea unei deschideri totale. Pe lângă târguri tradiționale, proximitatea unui teatru a prilejuit diverse spectacole în aer liber, pentru copii și adulți, beneficiind de topografia nou creată de rampe, scări, gradene.

A fost necesară desfacerea unui număr însemnat de copaci, dar pomii plantați depășesc numeric pe cei existenți înaintea intervenției, fiind distribuiți în aliniamente compacte pe margini, pentru a nu împiedica desfășurarea evenimentelor de amploare. Ei sunt prevăzuți cu grătare metalice dispuse la nivelul pavajului, în aceeași idee a accesibilizării întregului spațiu, și sunt din specii diverse: pe lângă pinii și brazii existenți înainte, au apărut cedri, platani, arbori lalea, corcoduși roșii, cireși japonezi, sicomori. În câțiva ani, ei vor oferi umbră și un spectacol cromatic acordat anotimpurilor.

Piatra propusă pentru pavaje și placări a fost andezitul, tăiat, spart sau fiamat, după caz, și dolomitul alb pentru marcaje de delimitare. Ne-am dorit și în general am reușit să avem un mobilier urban de calitate. Pe lângă piese de mobilier standard, s-au executat și tipuri de bănci personalizate: băncile jardinieră și cele mobile, care se adaptează la diversele evenimente din piaț̆. Lemnul aparent și oțelul vopsit în gri închis al băncilor contrastează plăcut cu griul deschis al pietrei. Lungimea de circa 60 de metri a scări monumentale din piatră masivă este ritmată de șase jardiniere din corten, cu o cromatică apropiată de cărămida aparentă a bisericii monument Cuvioasa Paraschiva și de țigla acoperișurilor blocurilor din frontul de vizavi, pe care scara se profilează

Iluminatul public urmărește atât conturu rectangular al pieței, cât și direcția diagonală, prin prevederea unor stâlpi mai mari. De asemenea, rampa diagonală, dincolo de aspectul utilita destinat persoanelor cu dizabilități, pare a fi, după cum ne-am și imaginat, o zonă preferată de o varietate de utilizatori: pietoni, mici bicicliști sau trotinete, beneficiind și de zonele de stat cele mai bune, cu umbră și perspective favorabile.

Noile străzi pietonalizate, precum si trotuarele lărgite au potențialul de a revigora activitățile comerciale ale parterurilor aferente, deschiderea de noi terase, iar succesul acestora se va răsfrânge si asupra imobilelor din jurul noii amenajări, care au

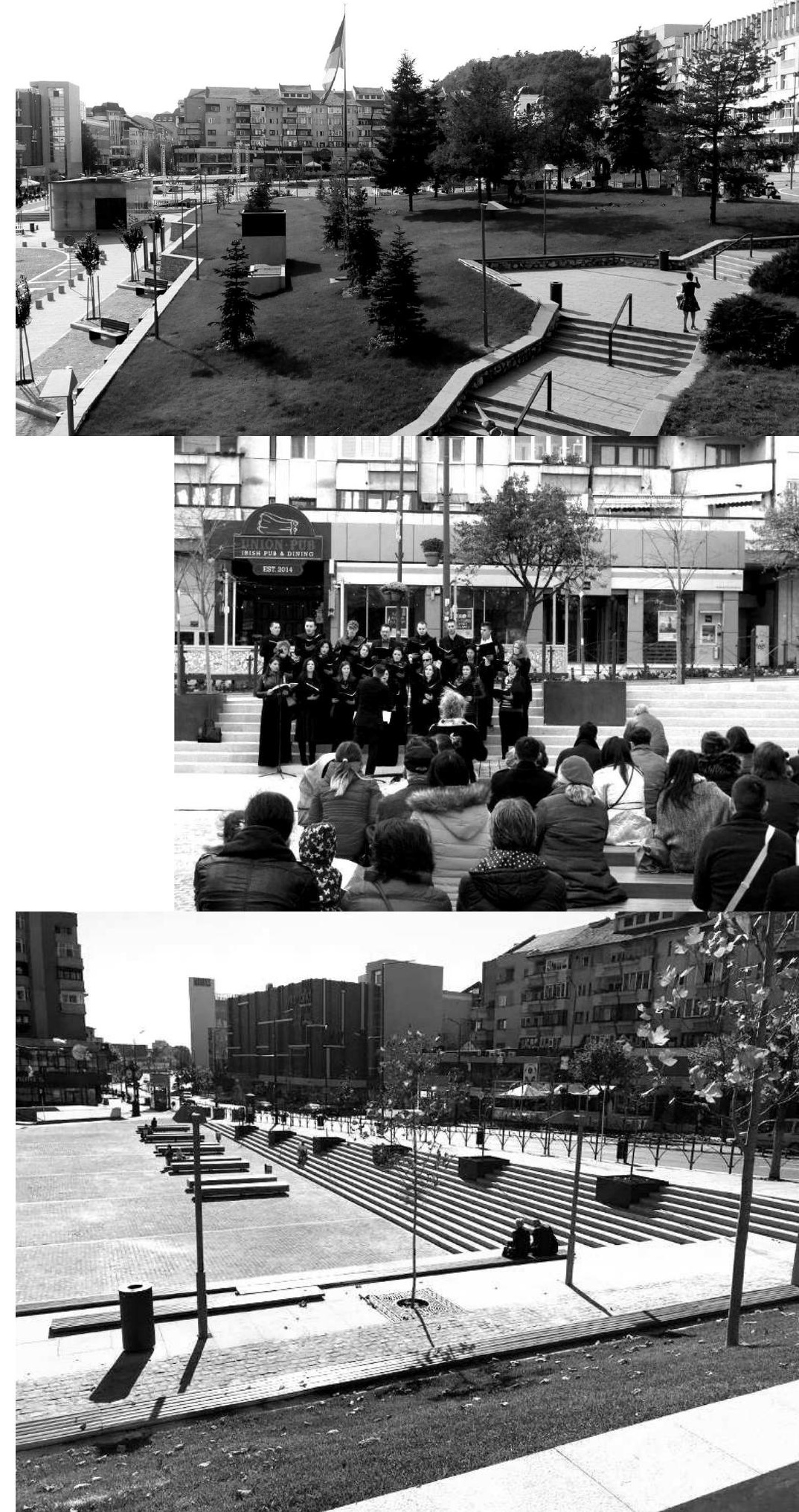



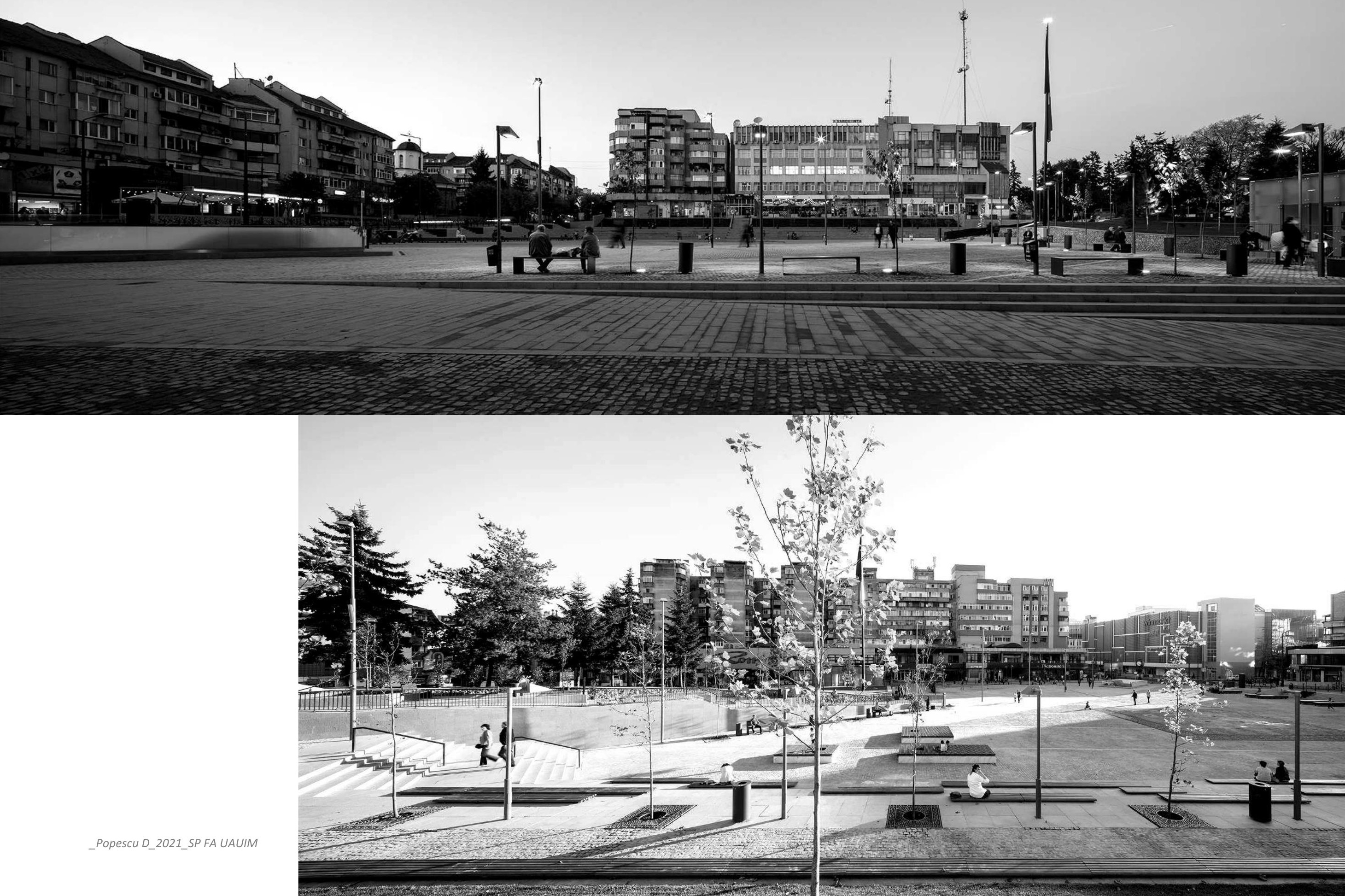


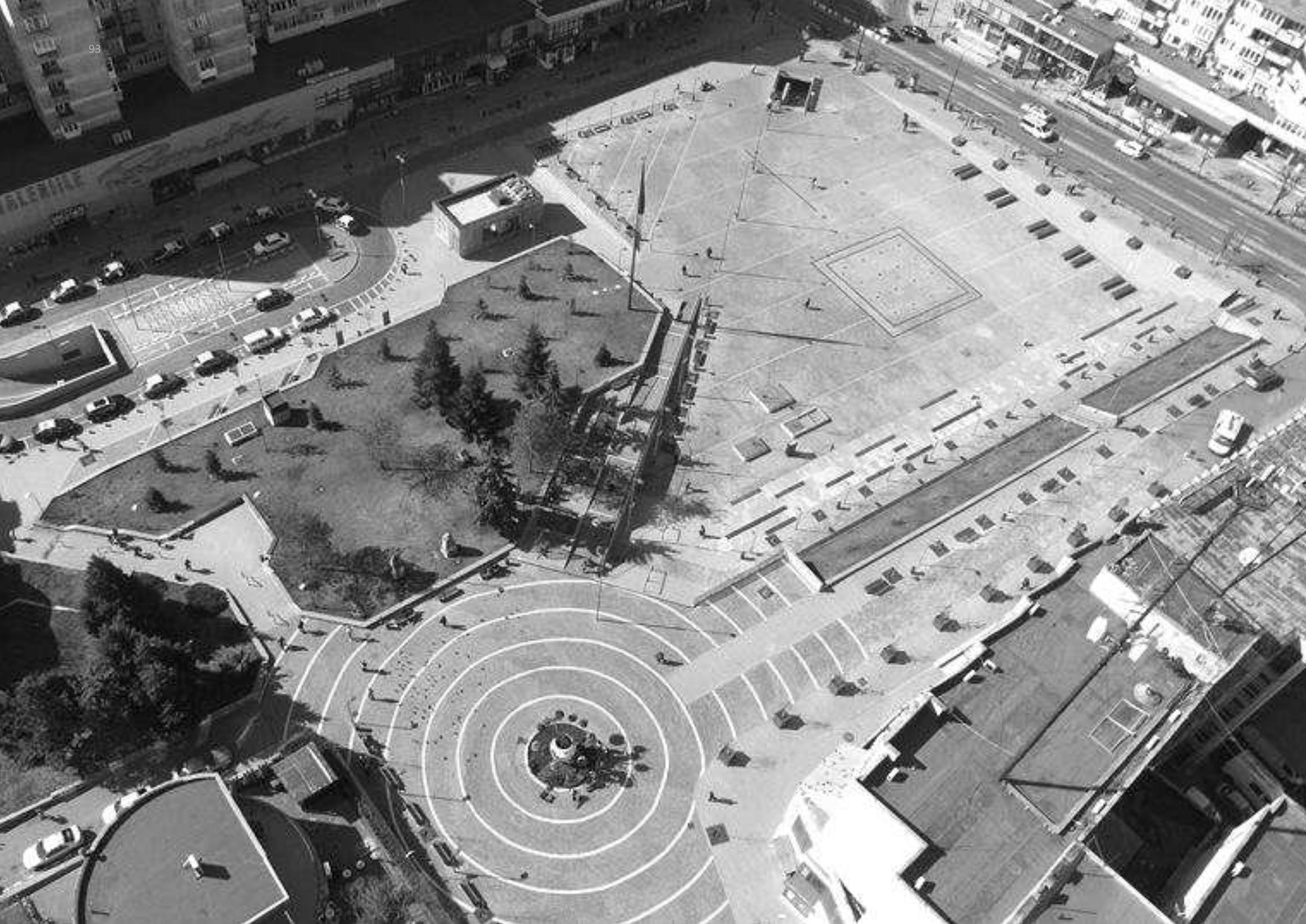




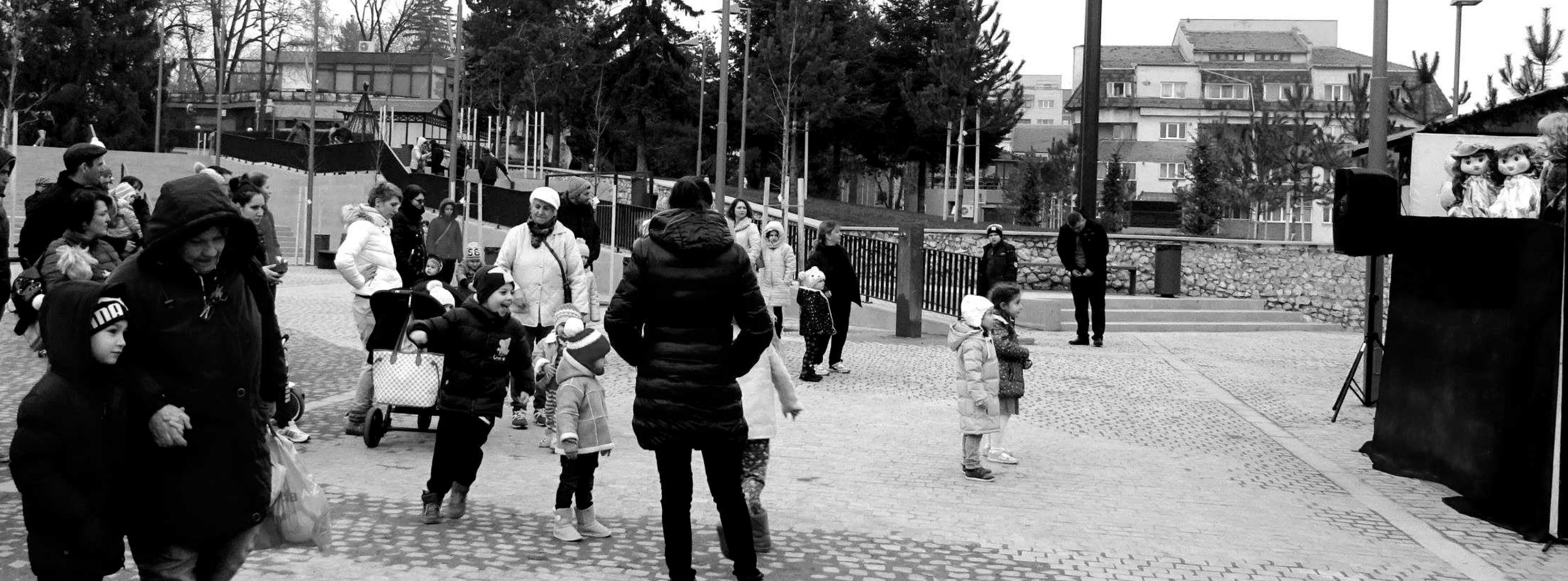




\section{PREVIOUS STATE}

Râmnicu Vâlcea is a small-to-medium size city, the head of one of Romania's 42 counties. It's located in the centre of the country, at the foothills of the Carpathian Mountains. The central area of the town was the subject of a national architectural competition in 2012. There were two areas to intervene upon: a larger one, aiming at the creation of pedestrian zones, new public spaces and their connections with the rest of the central area. A second focus was on a very central space, having a park-like organization at the time, which was to be converted into a major public space.

When we engaged in the 2012 national public competition to refurbish the city centre of Râmnicu Vâlcea, that we eventually won, our first impression was that the main problem of the site was just that it had an obsolete design and understanding of the public space.

The centre had previously suffered a rather brutal intervention in the 60's to 80's, most of the old houses and streets being replaced with blocks of flats and larger avenues. One central island, with a diagonal street, had been converted into the city's central public space, having a park-like design, with alleys, sloping green space and small paved platforms at different heights.

\section{AIM OF THE INTERVENTION}

The post war totalitarian regime in Romania had always feared large spontaneous gatherings of people, that's why a common feature of public space design in communist Romania was the park-type organization: alleys between green spaces, the best response to a "Keep walking, comrades, and keep contributed to social alienation and the destruction of the concept of community.

With our proposal, we wanted to recreate a democratic space that would help to re-enable a sense of local community, the civic and participatory spirit. We sought not to redesign and erase almost everything, as the previous intervention had done, but to identify and keep the valuable features and update the area to a contemporary understanding and use of the public space, which we basically considered to be a larger flat open space. The initial gradens-like platforms, as well as the entire park-like organization, were not friendly to large crowds of people. We had to "make space", keeping it horizontal and mineralized the green areas, replacing the grass with pavement and grid protections for the trees.

\section{DESCRIPTION OF THE INTERVENTION}

We identified the areas which could be kept as they were. In this respect, we preserved a major area of green space situated at the south-east of the site as it was, thanks to its qualities and the good connection it provided with the surroundings. We unified the other green spaces and platforms of the park into one large rectangular space, The Large Square. The old trees, initially evenly distributed on the green spaces, would be removed and we would plant new ones on the sides of the square, so that they didn't obstruct the view when large events occurred.

Due to a three-meter difference in height on the north-south direction of the site, and one meter on the east-west direction, we decided to lower the new square's level. Thus, the new configuration partially resembles to an open air amphitheatre. Its "zero" 
ramp are the usual users and activities spotted on site. The sitting places along the ramp offer shadow and a good view towards the square.

The newly pedestrian-designed streets and the enlarged sidewalks have the potential for reviving commercial activities such as pubs and open air terraces and this welfare may extend to the buildings surrounding the square, which are in need of a facelift.

We hope that the Square will in time fulfill its purpose as an agora for the city, where the people can celebrate but also show their disagreements, much needed in a young democracy such as the Romanian one.

\section{Credite / Credits:}

Beneficiar / Beneficiary : Primăria Municipiului Râmnicu-Vâlcea / Râmnicu-Vâlcea City Hall

Proiectant / Designer : Asocierea / Association SORIN DRAGOȘ POPESCU B.I.A. (arhitectură / architecture) - DUCTILTECH CONSTRUCT SRL (rezistență / structure) - COMPLET INSTAL DESIGN SRL (instalații / installation equipments)

\section{Subcontractanti proiectare / Subcontractors design}

Teleteknika Engineering SRL - devieri telecomunicații / telecommunications deviations, SC ELECTROINSTAL SOLUTION SRL- ELECTRICE, Proimsat S.A. - devieri electrice / electric deviations.

Echipa de arhitecți / Architects Team : arh. / arch. Dragoș Popescu, arh. / arch. Șerban Marinescu, arh. / arch. Bogdan Vitec, arh. / arch. Alexandru Pop

Colaboratori / Collaborators : arh./ arch. Rodica Stănică, peisagist / landscape designer Alexandru Pripiș

Constructor / Constructor : Asocierea MITLIV EXIM SRL POLYSTART IMPEX SRL
Subcontractanți instalații / Subcontractors installation equipments : CIVITAS SYSTEMS SRL

Suprafața supraterană amenajată / Ground Designed Area : cca. $17200 \mathrm{mp} / \mathrm{sqm}$

Suprafața construită supraterană (accese parcare, lifturi pasaj) Ground Built Area (parking accesses, passage elevators): $82 \mathrm{mp}$ / sqm

Suprafața construită subterană (parcare, pasaj) / Underground Built Area (parking, passage) : 8070,5 mp / sqm

Proiectare / Project : 2013

Execuție / Built : 2015-2017

Valoarea lucrărilor / Budget : cca. 48.400 .000 le

Echipa concurs / Competition Team : arh. Dragoș Popescu, arh. Șerban Marinescu, arh. Bogdan Vitec, arh. Alexandru Pop colaboratori arhitectură / architecture collaborators : st. arh. Niculae Theodoru Adrian, st. arh. Gherman Cătălin Ovidiu; colaborator deviz / budget collaborator : ing. Florentina Cârlan

Text / Text : Dragoș Popescu

Foto / Photo : Radu Malașincu, Șerban Marinescu, Alexandru Cutelecu, pagina oficială de Facebook "Primăria Municipiului Râmnicu Vâlcea" / Facebook official page of Râmnicu-Vâlcea City Hall

\section{Citare articol curent / Citation}

(Ro)

Popescu D. (2021). De la parc totalitar la piață democatică Reorganizarea și amenajarea spațiului public central din municipiul Râmnicu Vâlcea. în Teoria proiectului de arhitectură. Idei construite. SP FA UAUIM. EUIM - Editura Universitară Ion Mincu, București.

(En)

Popescu D. (2021). From totalitarian park to democratic plaza. Reformation and design of central public space from Râmnicu Vâlcea municipality. in Architectural design theory. Built ideas. SP FA UAUIM. EUIM - Ion Mincu University Publishing House, Bucharest. 

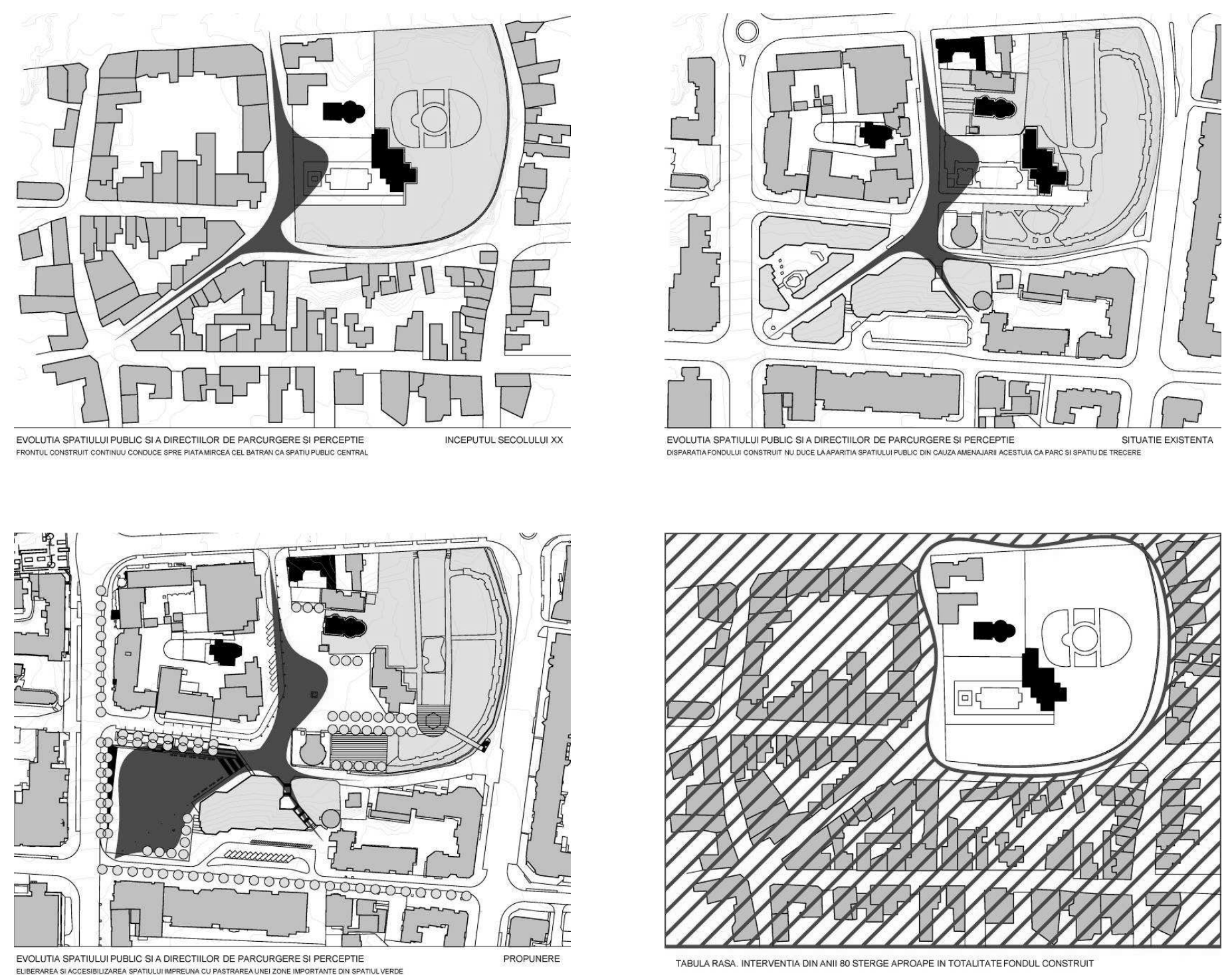


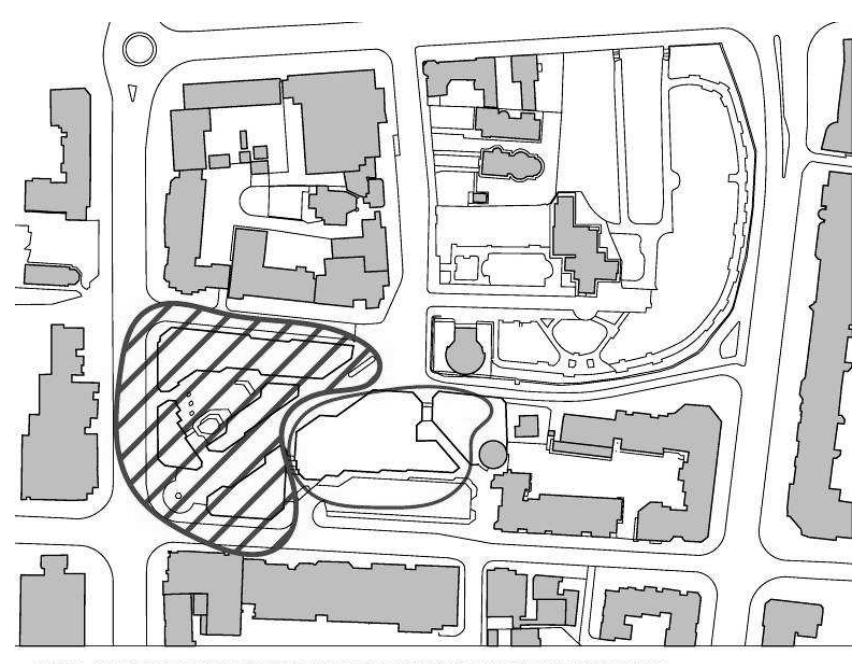

PASUL 1: I IENTIFICAREA ZONELOR CE SE VOR PASTRA SI MINMIZAREA ZONEI DE ITTERVENTIE

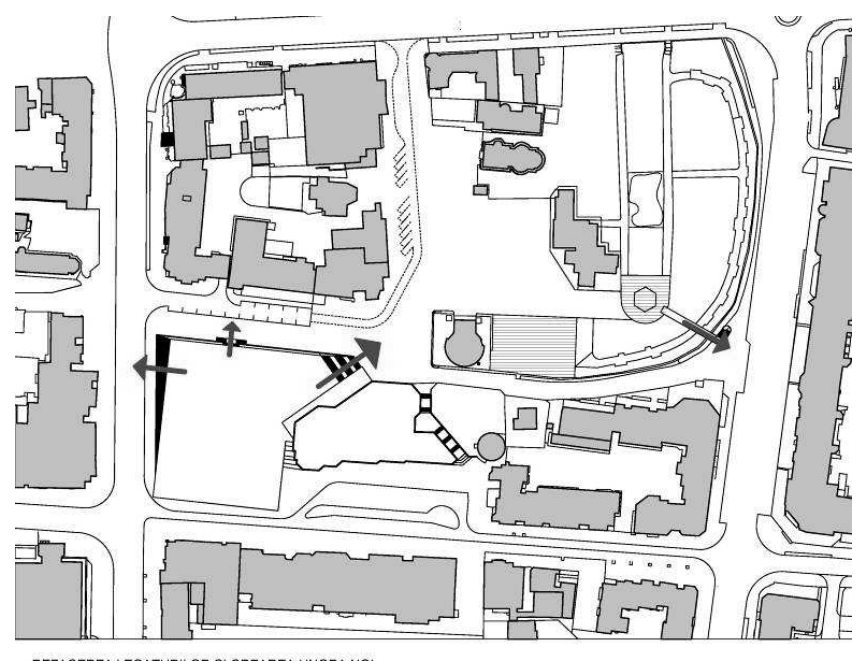

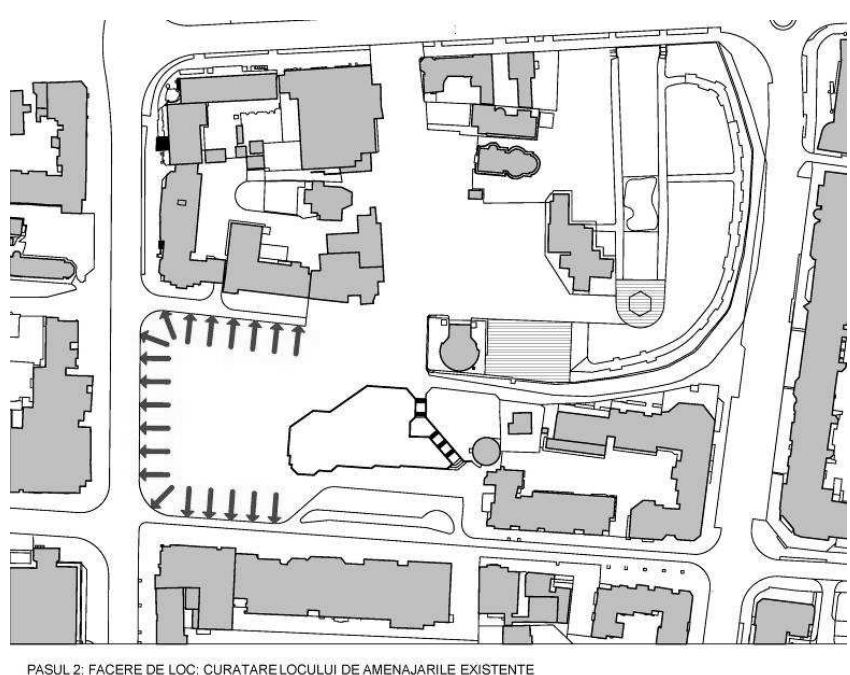
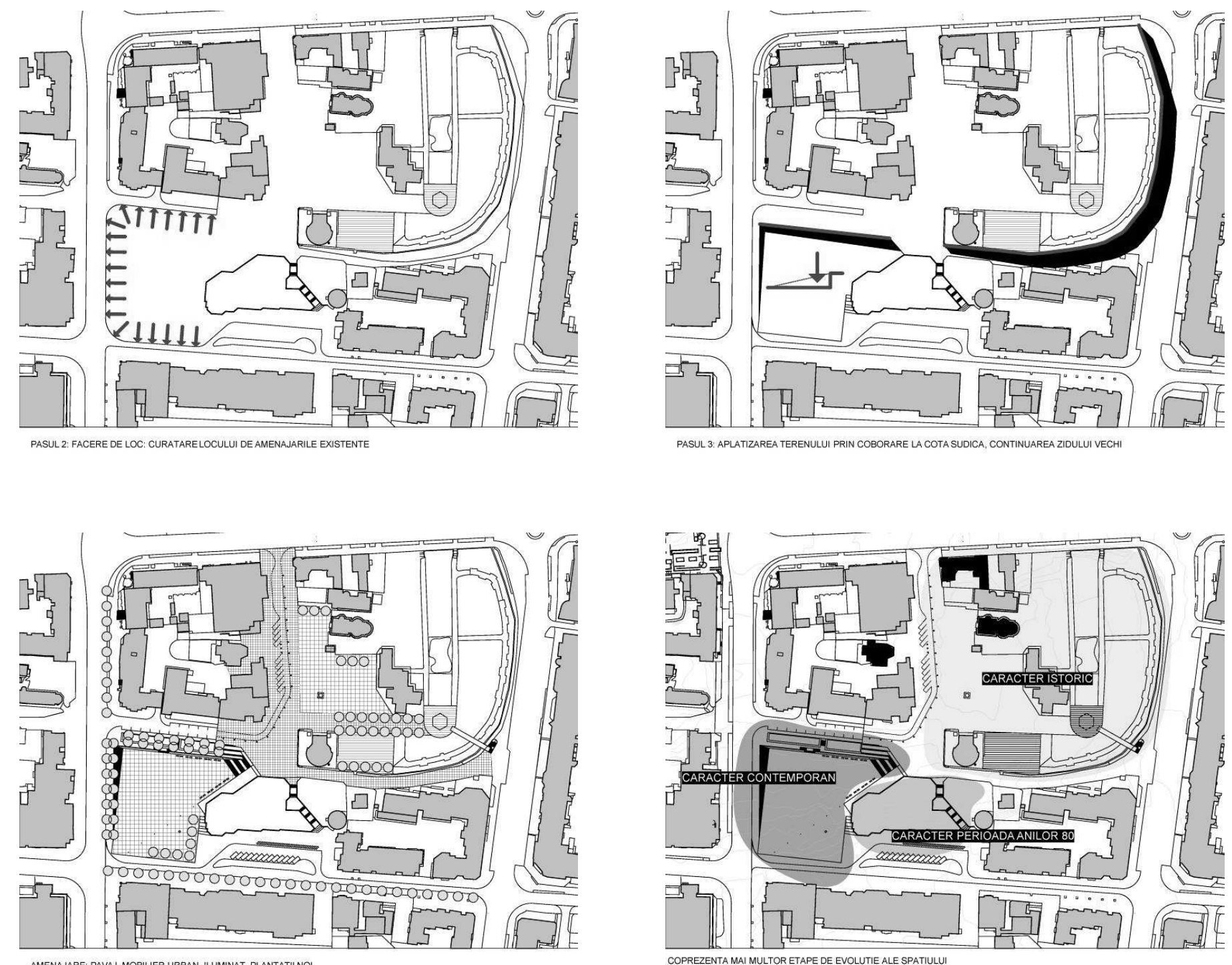


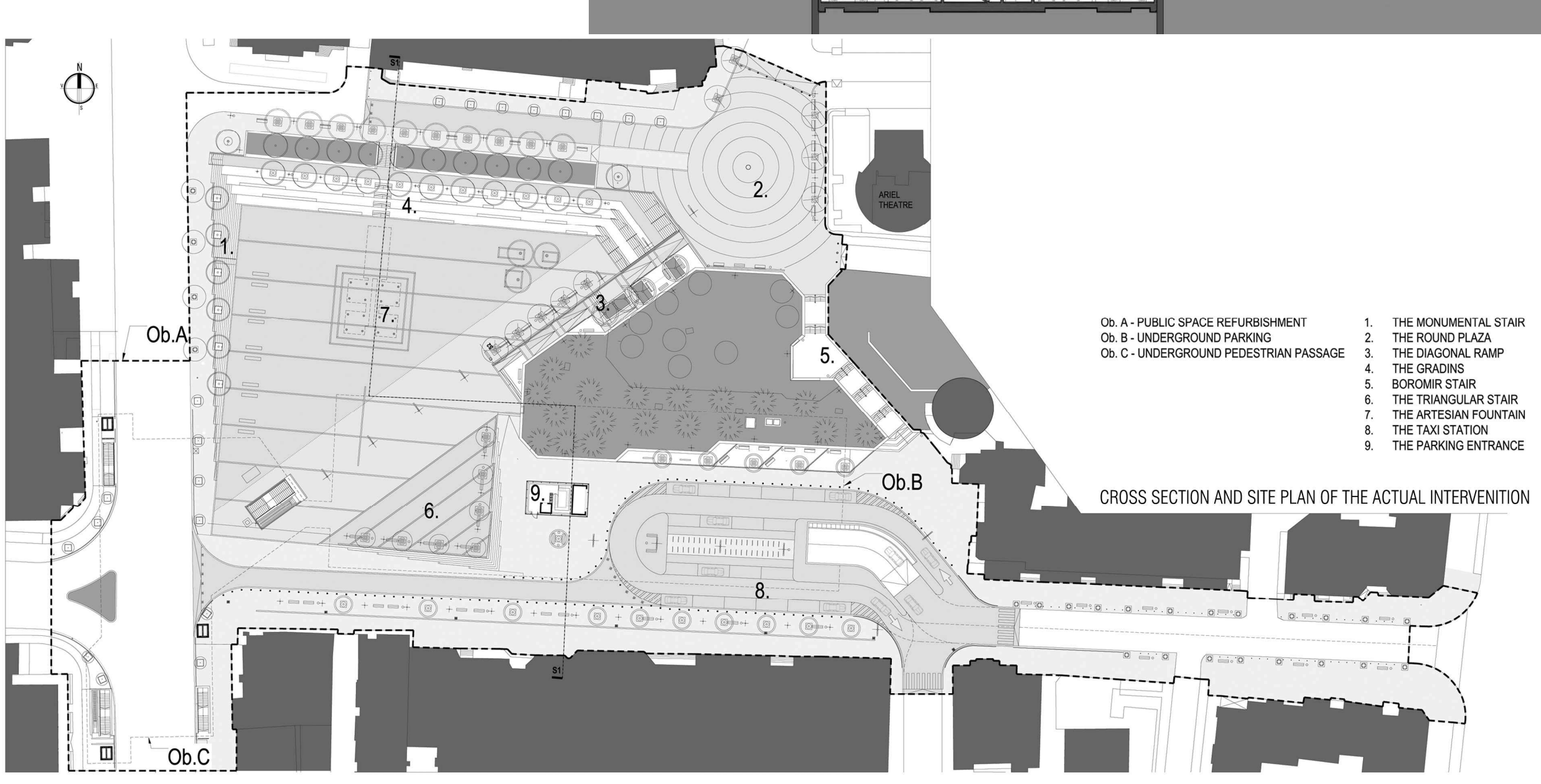




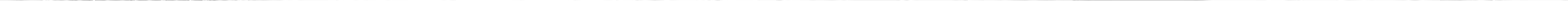

